\title{
Chapter 4 \\ Between Choice and Stigma: Identifications of Economically Successful Migrants
}

\author{
Marianne van Bochove and Jack Burgers
}

The documentary Dutch-Moroccan film maker Abdelkarim El-Fassi made about his father received much attention in Dutch media in 2014. One of the reasons probably was its unusual title: My Father, the Expat (in Dutch: 'Mijn vader, de expat'). With his film, El-Fassi wanted to shed new light on his father's migration experience, who, instead of as an 'expat', was dominantly perceived as a 'Moroccan guest worker'. In daily speech, the terms 'expat' and 'guest worker' both refer to people who temporarily moved from one country to another because of their work, but there is an important difference: expats are usually associated with high incomes and luxurious lifestyles, while guest workers are linked to low-skilled jobs and socioeconomic deprivation. El-Fassi's documentary essentially deals with the issue of identity construction. The label or 'master status' his father had in the receiving society did not coincide with how he perceived himself. El-Fassi, born in a small town in the Netherlands - he moved to Rotterdam to attend university - and as a successful film maker part of the Dutch cultural elite, also has to deal with the difference between the identity society imposed on him and the identity of his choice. In an interview in De Volkskrant newspaper (23 February 2015), he said that he is often invited for talk shows to discuss issues such as integration, Islam and Moroccans, while he would rather talk about his field of expertise: making films.

In this contribution, we further draw on El-Fassi's unusual but interesting comparison between 'immigrants' and 'expats', with the aim of scrutinizing identity construction and the tensions between stigma and identity of choice against the

\footnotetext{
M. van Bochove $(\triangle)$

Erasmus School of Health Policy \& Management, Erasmus University Rotterdam,

Rotterdam, The Netherlands

e-mail: vanbochove@eshpm.eur.nl

J. Burgers

Erasmus School of Social and Behavourial Sciences, Erasmus University Rotterdam,

Rotterdam, The Netherlands

e-mail: burgers@essb.eur.nl
} 
background of the (reluctant) superdiverse city of Rotterdam. We focus on two types of socioeconomically successful migrants which, despite their similarities in class position, are generally regarded as rather different. First, middle-class migrants and members of the second generation from 'classic' migration groups in the Netherlands (with roots in Surinam, Turkey and Morocco, including descendants of former guest workers). Second, expatriates or knowledge workers of various national backgrounds (including American, English, Indian, Chinese) who came to the Netherlands on a temporary basis because of their highly-skilled jobs (or the jobs of their partners, as we also included trailing spouses). In a city in which diversity is dominantly associated with problems (see Van Houdt and Schinkel, Chap. 7 in this volume), both groups usually do not receive much attention. While Rotterdam has recently adopted policy measures to become more attractive for highly skilled migrants, for instance reflected by the opening of an Expat Desk that offers all kinds of practical support, the migrant middle-class already present forms a largely ignored population category (Reijndorp and van der Zwaard 2004).

Earlier research paid attention to the identifications of children of migrants in Rotterdam and to the fact that an increasing part of them acquired middle or upper class status (see the contributions of Crul, Lelie and Keskiner, and Entzinger, Chaps. 3 and 9 in this volume, respectively). In addition, in this chapter, we argue that we can better understand the (imposed and chosen) identities of middle-class migrants and the second generation from 'classic' sending countries if we compare them with those of highly-skilled temporary migrants, and vice versa. We address the questions of how these migrants perceive themselves, how they think that others perceive them, and how discrepancies between these two affect their feelings of belonging in the city of Rotterdam and the Netherlands. Our findings suggest that while both 'immigrants' and 'expatriates' combine various identities, immigrants have more difficulty to adopt alternative identities (such as 'cosmopolitan') than expatriates because of their dominant label as 'allochtoon' (non-native Dutch).

\subsection{Middle-Class Immigrants and Expatriates in Rotterdam}

Rotterdam is sometimes characterized as 'a rich city with poor people' (Schrijnen 2004: 166). Apart from the fact that the city has one of the largest ports in the world, Rotterdam is 'heading the wrong lists', as the then mayor, Ivo Opstelten, said in 1999 (De Volkskrant, 1 November 1999), referring to the fact that Rotterdam had higher unemployment rates, lower income levels and lower educated people than other large Dutch cities. Immigrants of non-western origin were, and still are, overrepresented in the categories of unemployed and low-skilled people. However, in accordance with the conceptualization of 'superdiversity' as the diversification of diversity itself (see Vertovec 2007 and the contribution of Crul, Lelie and Keskiner, Chap. 3 in this volume), it is increasingly difficult to predict a person's income or educational level based on his or her ethnic background. A person that is registered as 'Turkish' in the municipal personal record database can be a lower-class former 
guest worker, but also a middle-class member of the second generation with a successful business (Rusinovic 2008), and, more and more often, a 'knowledge migrant' working here on a temporary basis (IND 2013).

An increasing percentage of inhabitants of the Netherlands with a Surinamese, Turkish and Moroccan background (first and second generation) belongs to the middle-class. According to Dagevos et al. (2006), this was one-third of the Surinamese population and about one-sixth of the Turkish and Moroccan population (this group doubled in size between 1991 and 2005). Although comparable figures are not available at the city level, Rotterdam, like other large Dutch cities, is potentially an important location for the formation of an immigrant middle-class. The percentage of international knowledge workers in the Netherlands has increased over the past years. Compared with Amsterdam - the only 'global city' in the Netherlands, according to Sassen's criteria - Rotterdam's expat population is relatively small. Research on the presence of highly skilled migrants in various metropolitan areas in the Netherlands showed that in 2013, the Rotterdam area numbered 37,300 international knowledge workers (against 27,500 in 2009), of whom 21,000 live in the city of Rotterdam (Decisio 2015a). They comprise about $3.5 \%$ of the total population. The number of expats in the Amsterdam metropolitan area is considerably larger: 104,900 in 2013 (84,500 in 2009), of whom almost 42,000 live in the city of Amsterdam (which is more than $5 \%$ of the city's total population) (Decisio 2015b). The countries of origin are quite similar for both cities: Germany and the UK are important sending countries. In Rotterdam, the share of Turkish knowledge workers is remarkably high; they form the second largest group after the Germans (Decisio 2015a).

The findings we present in this chapter are based on data collected between 2007 and 2009 for the Transnational and Urban Citizenship project (see Van Bochove et al. 2010, 2015; Van Bochove 2012a, b; Van Bochove and Engbersen 2015; Snel et al. 2016). ${ }^{1}$ The research team interviewed 225 middle-class (children of) immigrants of Surinamese, Turkish and Moroccan origin, which represent the three largest immigrant groups in Rotterdam. We further refer to this group as 'middle-class migrants' Furthermore, 75 highly-skilled temporary migrants and trailing spouses (from, among other countries, the US, the UK, Germany, India, China, Japan, Turkey, and South Africa) were interviewed, to which we further refer as 'expatriates' or 'expats'.

Middle-class migrants were selected based on job level (at least intermediate vocational education) and/or income level (above the national median income). The respondents are part of the 1st, 2nd, or 1.5 generation. The expatriates were selected on their - or in the case of trailing spouses: their partners' - job level (at least higher vocational education) and current length of stay in the Netherlands (between 6 months and 6 years). The respondents were recruited through snowball sampling. Starting

\footnotetext{
${ }^{1}$ The fieldwork has been done about 10 years ago. Although the socioeconomic context has changed significantly since then, notably in terms of the financial crisis and its aftermath, we have no reason to expect that the identifications of the middle-class first and second generation and expatriates have changed dramatically since then. Given the recent rise of political parties that, in a reaction to right-wing populist parties, explicitly focus on the non-native Dutch electorate, we may expect that the 'ethnic' identifications of migrants in Rotterdam have intensified rather than diminished.
} 
points were the interviewers' own social networks, businesses, organizations, and meetings. The interviews generally lasted between 1 and $2 \mathrm{~h}$. The research team used a questionnaire consisting of both closed and open-ended questions relating to the respondents' jobs, migration history, nationality, family situation, and their identifications and practices regarding different geographical scales. In this chapter, we draw on quantitative closed-ended questions about the respondents' identifications (how they perceive themselves and how they think others perceive them) and on open-ended questions in which respondents were asked to motivate or to further explain their answers.

\subsection{Chosen and Imposed Identifications: From World Citizen to Allochtoon}

It is generally acknowledged that identities are context dependent and multidimensional. Because of this, the concept 'identification' is usually preferred to 'identity', to stress the fact that it concerns a process rather than a static entity (cf. Nederveen Pieterse 2007: 32; WRR 2007: 33). This does not mean, however, that identities are completely fluid and matters of mere choice (Verkuyten 2005: 54). First of all, certain aspects of identity are more stable than others (Van Bochove et al. 2015). Identifications based on gender, ethnicity and religion are usually established at an early age and are generally less flexible than identifications with, for instance, sports clubs or social movements (Verkuyten 2005: 54; Jenkins 1996). Second, not every identity adopted by an individual is accepted by others (Woodward 2004: 7). This is important, since identities are always constructed in relation to others. As Berger and Berger (1972: 62) put it: 'Only if an identity is confirmed by others it is possible for that identity to be real to the individual holding it.' Both notions - that some parts of identity are relatively stable and that it is difficult to adopt an identity that is not accepted by others are important for the interpretation of the findings presented below.

The middle-class migrant and expatriate respondents were asked what their primary self-identity is (the exact question was: 'What do you feel yourself to be in the first place?) and how they think they are perceived by others. For both questions, the respondents could choose from the following answer options: Dutch(wo)man; Rotterdammer; Surinamese/Turkish/Moroccan/American/English/German, etc. (the answer option varied according to the respondent's background); Allochtoon/foreigner (the former was used in the interviews with middle-class migrants, the latter in those with expatriates) ${ }^{2}$; Christian; Muslim; Hindu; European; World citizen/cosmopolitan; Other, namely ... In the case of the middle-class migrants, two other options were added: Dutch-Surinamese/-Turkish/-Moroccan and Surinamese-/ Turkish-/Moroccan-Dutch (we refer to both as a hyphenated identities). In the case of expatriates, 'expat' was included as an additional option. The tables below show the three most frequently given answers to both questions for both respondent groups.

\footnotetext{
${ }^{2}$ The terms 'allochtoon' and 'foreigner' do not have exactly the same connotation; we will come back to that later.
} 


\begin{tabular}{l|l}
\hline Middle-class migrants & \\
\hline Primary self-identity & Perceived by others \\
\hline Homeland identity $(35 \%)$ & Homeland identity $(33 \%)$ \\
\hline Hyphenated identity (16\%) & Allochtoon $(25 \%)$ \\
\hline Religious identity (14\%) & Hyphenated identity (16\%) \\
\hline
\end{tabular}

\begin{tabular}{l|l}
\hline Expatriates & \\
\hline Primary self-identity & Perceived by others \\
\hline Homeland identity $(41 \%)$ & Homeland identity $(37 \%)$ \\
\hline World citizen/cosmopolitan (21\%) & Foreigner (33\%) \\
\hline Expat (11\%)/foreigner (11\%) & Expat (13\%) \\
\hline
\end{tabular}

In the next section, we will discuss the narratives behind these answers, since it is important to know the concrete meanings respondents attribute to the general categories mentioned above. But the general findings in both tables in themselves already reveal striking patterns that are worth elaborating on here.

First, the importance of a 'homeland' identity stands out, both in the respondents' primary-self identities and in their ideas of how others perceive them. Even though in existing literature, expatriates are dominantly described as members of cosmopolitan or expat communities (e.g. Hannerz 1990; Castells 2000), our findings show that for a large part of both respondent groups, their (parents') country of birth provides an important element of their identity.

This is not to say that scholars who portray expatriates as cosmopolitans are entirely beside the mark: 16 out of 75 expatriates primarily identify themselves as world citizens/cosmopolitans. However, only three think others perceive them as such. This is a second striking finding: a cosmopolitan identity is one that is relatively often chosen among expatriates, but (in their opinions) rarely imposed on them or recognized by others.

A third finding that stands out, is that the reverse situation - an identity that is imposed but not chosen as a primary self-identity - is also prominent, but then among middle-class migrants. These respondents often answer allochtoon when asked how they think they are perceived by others ( 57 respondents), but only a few say they identify themselves as such (5 respondents).

A fourth and final finding that is noteworthy is the absence of Dutch (wo)man and Rotterdammer in the top three lists of both respondent groups. Of the middleclass migrants, about 6\% (13 respondents) said they primarily felt Dutch; of the expatriates none. The finding of previous research that migrants often experience a local or urban identity as more inclusive (Groenewold 2008: 110, see also Entzinger, Chap. 9 in this volume), is somewhat supported by our findings: 20 middle-class migrants (about 9\%) and one expatriate gave this answer. 


\subsection{Looking Behind the Categories}

The figures presented above provide first insight into the identity construction of middle-class migrants and expatriates in Rotterdam. However, several questions so far remained unanswered. Why do middle-class migrants have the feeling they are perceived as allochtoon? And what do expatriates mean when they say they feel like cosmopolitans? To answer these questions, we 'need to look behind the categories', as Kiely et al. (2005: 76) earlier did in their research on the construction of British identity.

\subsubsection{Feeling Perceived as Allochtoon}

Many of the middle-class respondents say that, although they are legally Dutch, they do not feel themselves to be 'real' Dutch (wo)men. Looking at the explanations they give for their answers, it appears that the respondents do want to feel Dutch, but that others exclude them from this identity. Two examples of such statements:

I want to feel like a real Dutchman, but because others don't see me that way, I can't. (Male middle-class migrant, 55, Surinamese origin)

I would like to feel like a Dutchman, but because of the way other people approach me, I feel Moroccan. (Male middle-class migrant, 31, Moroccan origin)

One female trailing spouse, who is excluded from the sample because she has lived in the Netherlands for about 15 years, makes a similar remark.

I think I can describe myself as a Dutchwoman, but because of my looks nobody thinks I am

Dutch. In America, everyone is American. They will not say 'you are Chinese', or 'you are

Turkish'. But in Rotterdam, I feel the people think 'you are Chinese', even if you belong to the second or third generation. (Female former expatriate, 51, Chinese origin)

Many of the respondents have the feeling that 'Dutchness' is reserved for native, white, non-Muslim people. The opposite of being native Dutch or 'autochtoon' is being non-native Dutch or 'allochtoon'. Although the middle-class migrants do not feel themselves to be allochtoon in the Netherlands - since they have lived here for a long time, have a Dutch passport, work here, and speak the language fluently they do experience the consequences of being labelled as such by other (native Dutch) people.

The label allochtoon is not perceived as a neutral description, referring to a factual foreign origin, but rather as a stigma. Middle-class migrants associate it with negative statements about immigrants, Muslims and Islam that have become more explicit in Dutch media and politics since the turn of the century. With the rise of right-wing politicians such as Geert Wilders and earlier Pim Fortuyn (discussed in detail in Chap. 5 by Van Ostaaijen), many middle-class migrants have established the feeling that they are not that welcome in the Netherlands anymore and some of them even think about moving abroad because of this reason. 
As an allochtoon you have to prove yourself two or three times more, you get underestimated a lot. I don't want that anymore. Since Wilders, it has become worse. I ask myself whether my children have a future in this country. (Male middle-class migrant, 52, Surinamese origin)

It is not always nice to live in the Netherlands if you are an allochtoon and certainly not if you are a Muslim. Particularly since about six years ago, with the rise of Pim Fortuyn, we are seen as second-class citizens. (Female middle-class migrant, 31, Moroccan origin)

I do not always feel welcome here. People think in terms of 'we' and 'them' and politicians encourage that. (Female middle-class migrant, 26, Moroccan origin)

Expats who feel themselves to be foreigners or think others perceive them as such usually do not see this identity as negative per se. In the explanations they give for their answers on the closed-ended questions, they often use the terms 'foreigner' and 'expat' in similar ways. While for middle-class migrants, allochtoon is a stigma and a sign of not being fully accepted as a Dutch citizen, for expats, the feeling of being perceived as foreigner actually comes close to how many perceive themselves in the Netherlands and Rotterdam: as persons coming from abroad who are likely to move on to the next destination or to return 'home' within a few years.

The expatriates generally do not know much about Dutch politics, but when they do know a politician or a political party, it is usually Geert Wilders and his Party for Freedom (PVV). That is to say, many do not know the exact names, but refer to them as 'the irritating xenophobic guy', 'the guy that bleaches his hair', 'that albino guy, the fascist', and his 'extreme right party'. Some of the expatriates say they worry about these developments. However, since they do not consider themselves to be Dutch anyway - some do not even see themselves as residents of the Netherlands - they regard the political climate as something that affects 'immigrants' more than 'expats'.

Some expatriates reflected on their relationship with 'immigrants' in Rotterdam. A Turkish and a Polish expatriate mentioned that there is a clear distinction between expats and other people coming from Turkey and Poland. This has to do with education and job level - like many Dutch people, they associate migrants from these countries with low-status jobs - but also with the level of integration. A Turkish expatriate says:

Well, there are two main groups of Turkish people here. The first group are the ones that came here a long time ago and they have Dutch citizenship. With that group, I am not close. They have a Dutch and a Turkish culture. But I also know PhD students from Turkey, I'm closer to them. (Female expatriate, 26, Turkish origin)

Despite the fact that many expatriates distinguish between expats and other migrant groups, some do feel a kind of companionship, based on a shared experience of being 'foreign'. An American trailing spouse says that while she often finds Dutch people quite rude, her experiences with 'immigrants' in Rotterdam are positive. 
Even people who are really strict Muslims ... Even if a woman wore a headscarf, I found out that those people are more helpful in giving me directions and showing me ... It is really interesting, it's like they think: 'we know you are foreign'. (Female trailing spouse, 34, American origin)

The middle-class migrants did not mention any encounters with expatriates. However, based on the interviews, we can conclude that many respondents from both groups appreciate the ethnic and cultural diversity of Rotterdam, which we will come back to in the next section.

\subsubsection{Feeling Like a Cosmopolitan}

Expatriates who primarily identify themselves as 'world citizens' or 'cosmopolitans' often explain their answers by saying that because they lived in (sometimes several) different countries, they find it difficult to choose one answer option. In their opinion, feeling like a world citizen comes closest to a multilayered identity. They emphasize that they do not belong to a single place and cannot be placed into a single box. The quote below is from an expatriate who, after some contemplation, chose the option world citizen.

I know that I am a foreigner, but we have this thing here with my friends that we are Rotterdamers. So, if I had to describe myself in Holland, I would say Rotterdammer. Maybe just for fun, but it feels a bit like it. I also feel a bit like a world citizen; I always travel. If you ask me if I feel Brazilian, yeah, I lived there most of my life and that is part of what I am. But I feel more international. I feel like I never fitted there so well, and I never fit here so well. So I don't know if I fit places. (Female expatriate, 29, Brazilian origin)

The fact that relatively more expatriates than middle-class migrants say their primary self-identity is cosmopolitan or world citizen might have to do with their differences in migration experiences: expatriates generally lived in more different countries than middle-class migrants, of whom many were born and/or raised in the Netherlands. Some of the middle-class migrants who chose this answer option also lived in more than two countries. One of them lived in Morocco, Belgium and the Netherlands and thinks about moving back to Morocco one day. The explanation she gives for her answer is similar to that of the Brazilian expatriate quoted above.

I find it difficult to say whether I feel more Moroccan or Dutch. As a matter of fact, I do not think the term 'feeling' is really helpful. In Morocco, I feel Dutch, and in the Netherlands I feel Moroccan. Actually I feel myself to be a Rotterdammer, a Muslim, a Moroccan, and a Dutchman. I feel like a world citizen. If it were up to me, all national borders would disappear. (Female middle-class migrant, 41, Moroccan origin)

As Hannerz (1990) argued, cosmopolitanism is not necessarily about having lived in many different places; it is a way of relating to increasing diversity. According to this view, a cosmopolitan is someone who enjoys the coexistence of different cultures. Many of the respondents, both expatriates and middle-class migrants, have such a positive stance towards diversity. Interestingly enough, their celebration of diversity is not so much mentioned in reference to their self-identity 
as world citizens or cosmopolitans, but rather when they talk about their bonds with what they call 'world cities' or 'cosmopolitan cities'. ${ }^{3}$ They, for instance, say that they feel close to 'London, because it's a melting pot of many different cultures', to 'New York, because of its ethnic mix' and 'Istanbul, because it is a big, beautiful city with a mix of cultures'.

Some respondents mention that Rotterdam does not have the same 'lifestyle' or 'vibe' as these world cities. Many others, however, embrace the city of Rotterdam because for them, it similarly represents cultural diversity. One middle-class migrant refers to the variety of available foods to illustrate this mix of cultures:

I feel connected with Rotterdam; I wouldn't want to live in any other city. I began to love this city. In Rotterdam, if you want to have nasi [an Indonesian rice dish] or kebab at four o'clock in the morning, you can just get it. (Male middle-class immigrant, 44, Surinamese origin)

It can be argued that in the Dutch context, Rotterdam - together with Amsterdam and possibly The Hague - is the city that comes closest to what many migrants see as their cosmopolitan ideal. An expatriate explains that in Rotterdam, compared to other areas in the Netherlands, he does not feel he is 'different'.

Specifically in Rotterdam - in other places it is different - a huge part of the population is foreign, so being a foreigner myself, I don't feel like I stick out particularly or that my presence is unusual. There is a significant presence of people from all over the world; that is something that I enjoy. (Male expatriate, 38, Italian origin)

While the expatriate quoted above sees it is a positive thing to be 'one of the many foreigners' in Rotterdam, for middle-class migrants, being perceived as a 'foreigner' or 'allochtoon' is actually often experienced as insulting, as we discussed earlier. While the feeling of being perceived as allochtoon is particularly mentioned in relation to the political climate on a national level, some respondents also experienced a change in their beloved Rotterdam. One of them - the same respondent who called herself a 'world citizen' - describes how her identity as a Rotterdammer has weakened over the past years.

For years, I felt myself to be a citizen of the city. But that changed some years ago. In the past, when I had been in Belgium for family visit and the train to Rotterdam passed the Turkish mosque, it really felt like coming home. But now, people see me as an allochtoon. (Female middle-class migrant, 41, Moroccan origin)

With their multilayered identities, relating to different national, cultural and religious backgrounds, both expatriates and middle-class migrants feel at home in 'cosmopolitan', ethnically diverse cities. However, while to many middle-class migrants, Rotterdam represents (super) diversity, they have the feeling that others think Rotterdam should represent 'whiteness' or 'being native Dutch'. As long as this is the case, and their identities as Rotterdamers or world citizens are not confirmed by others, such identities are also difficult to be real to the persons holding them (Berger and Berger 1972).

\footnotetext{
${ }^{3}$ One of the open questions was, whether respondents felt a special bond with places (cities, countries or regions) apart from Rotterdam, the Netherlands and their country of origin.
} 


\subsection{Part of a Superdiverse Population: But Still Put into a Single Box}

Rotterdam can be characterized as a superdiverse city: there are multiple layers of difference within its immigrant populations, including country of origin, mode of migration, nationality, socioeconomic position, language, and religion. However, this does not mean that this condition of superdiversity is acknowledged, let alone embraced, by the urban population. Rather, we see forms of reduction of the complexity that superdiversity poses in everyday life. More specifically, superdiversity is often simplified to dichotomies, such as 'autochtoon' versus 'allochtoon' or 'Dutch' versus 'foreign'. Even though middle-class migrants say they feel connected with Rotterdam because of its diverse population, they also feel they are put into a single box, rather than having the feeling that their multiple identities are accepted. And even though expatriates sometimes feel themselves to be cosmopolitans or world citizens, they are also very much aware of the fact that they are 'foreigners', which means not being at home even in a superdiverse city. Interestingly, middle-class migrants and expatriates alike reproduce the dichotomies they think the dominant - not necessarily majority - population group uses to make sense of everyday urban superdiversity. They also (often implicitly) refer to people who are 'autochtoon' or 'Dutch', as if these were homogeneous categories. In that sense, redefining him from 'guest worker' to 'expat' would not have solved the feeling of social exclusion - not being 'native' - perceived by Abdelkarim El-Fassi's father.

\section{References}

Berger, P., \& Berger, B. (1972). Sociology: A biographical approach. New York: Basic Books Publishers.

Castells, M. (2000). The rise of the network society. Oxford: Blackwell Publishers.

Dagevos, J., Hoff, S., \& Soede, A. (2006). Minderheden in de middenklasse. In Sociaal en Cultureel Planbureau (Ed.), Investeren in vermogen: Sociaal en cultureel rapport 2006 (pp. 117-152). Den Haag: SCP.

De Volkskrant. (1999, November 1). Rotterdam: ambitieuze overdaad. http://www.volkskrant.nl/ binnenland/rotterdam-ambitieuze-overdaad a526244/.

De Volkskrant. (2015, February 23). 'Het is een privilege je niet bezig te houden met je afkomst': Interview Abdelkarim El-Fassi. http://www.volkskrant.nl/ leven/-het-is-een-privilege-je-niet-bezig-te-houden-met-je-afkomst a3871775/

Decisio. (2015a). Infographic regio Rotterdam: Internationale werknemers regio Rotterdam. (Made available to the authors by Rotterdam Info Expatdesk).

Decisio. (2015b). Infographic regio Amsterdam: Internationale werknemers MRA. (Made available to the authors by Expatcenter Amsterdam).

Groenewold, G. (2008). Identities and intercultural relations. In M. Crul \& L. Heering (Eds.), The position of the Turkish and Moroccan second generation in Amsterdam and Rotterdam. The TIES study in the Netherlands (pp. 105-127). Amsterdam: Amsterdam University Press.

Hannerz, U. (1990). Cosmopolitans and locals in world culture. Theory, Culture and Society, 7(2), 237-251. 
IND. (2013). Monitor kennismigranten: kwantitatieve analyse. Rijswijk: IND Informatie- en Analysecentrum. https://ind.nl/Documents/2013\%20Monitor\%20Kennismigranten,\%20 Kwantitatieve\%20analyse.pdf

Jenkins, R. (1996). Social identity. London: Routledge.

Kiely, R., McCrone, D., \& Bechhofer, F. (2005). Whither Britishness? English and Scottish people in Scotland. Nations and Nationalism, 11(1), 65-82.

Nederveen Pieterse, J. (2007). Ethnicities and global multiculture: Pants or an octopus. Lanham: Rowman \& Littlefield Publishers.

Reijndorp, A., \& van der Zwaard, J. (2004). Op zoek naar de middenklasse. In F. Becker, W. R. van Hennekeler, M. Sie Dhian Ho, B. Tromp, \& M. Linthorst (Eds.), Rotterdam: het vijfentwintigste jaarboek voor het democratisch socialisme (pp. 82-108). Amsterdam: Mets \& Schilt/ Wiardi Beckman Stichting.

Rusinovic, K. (2008). Transnational embeddedness: Transnational activities and networks among first-and second-generation immigrant entrepreneurs in the Netherlands. Journal of Ethnic and Migration Studies, 34(3), 431-451.

Schrijnen, J. M. (2004). De ruimte van Rotterdam. In F. Becker, W. R. van Hennekeler, M. Sie Dhian Ho, B. Tromp, \& M. Linthorst (Eds.), Rotterdam: het vijfentwintigste jaarboek voor het democratisch socialisme (pp. 157-171). Amsterdam: Mets \& Schilt/Wiardi Beckman Stichting.

Snel, E., M. 't Hart, M. van Bochove (2016) Reactive transnationalism: Homeland involvement in the face of discrimination. Global Networks (early view online).

Van Bochove, M. (2012a). Truly transnational. The political practices of middle-class migrants. Journal of Ethnic and Migration Studies, 38(10), 1551-1568.

Van Bochove, M. (2012b). Geographies of belonging. The transnational and local involvement of economically successful migrants. Doctoral dissertation. Rotterdam: Erasmus University.

Van Bochove, M., \& Engbersen, G. (2015). Beyond cosmopolitanism and expat bubbles: Challenging dominant representations of knowledge workers and trailing spouses. Population, Space and Place, 21(4), 295-309.

Van Bochove, M., Rusinovic, K., \& Engbersen, G. (2010). The multiplicity of citizenship: Transnational and local practices of middle-class migrants. Global Networks, 10(3), 344-364.

Van Bochove, M., Burgers, J., Geurts, A., de Koster, W., \& van der Waal, J. (2015). Questioning ethnic identity: Interviewer effects in research about immigrants' self-definitions and feelings of belonging. Journal of Cross-Cultural Psychology, 46(5), 652-666.

Verkuyten, M. (2005). The social psychology of ethnic identity. Hove: Psychology Press.

Vertovec, S. (2007). Super-diversity and its implications. Ethnic and racial studies, 30(6), $1024-1054$.

Woodward, K. (2004). Questioning identity: Gender, class, ethnicity. London: Routledge.

WRR. (2007). Identificatie met Nederland. Amsterdam: Amsterdam University Press.

Open Access This chapter is licensed under the terms of the Creative Commons Attribution 4.0 International License (http://creativecommons.org/licenses/by/4.0/), which permits use, sharing, adaptation, distribution and reproduction in any medium or format, as long as you give appropriate credit to the original author(s) and the source, provide a link to the Creative Commons license and indicate if changes were made.

The images or other third party material in this chapter are included in the chapter's Creative Commons license, unless indicated otherwise in a credit line to the material. If material is not included in the chapter's Creative Commons license and your intended use is not permitted by statutory regulation or exceeds the permitted use, you will need to obtain permission directly from the copyright holder.

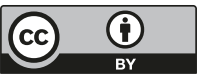

